Dikirim: 30 November 2016 Diterbitkan: 1 April 2017

\section{Sikap, beban kerja dan kelelahan kerja pada pekerja pabrik produksi aluminium di Yogyakarta}

\section{Attitude, workload and fatigue among aluminum production factory workers in Yogyakarta}

\author{
Bambang Hermawan $^{1}$, Widodo Haryono ${ }^{1}$, Soebijanto Soebijanto ${ }^{2}$
}

\begin{abstract}
Purpose: This study aimed to determine the effect of age, occupation, nutritional status, sleep duration, smoking habit of work attitude and work load to work fatigue on factory workers of "SP" alumunium unit of Yogyakarta. Methods: This research was an observational analytic study using a cross-sectional design. The population was 153 people. The sample was taken based on the total sampling on the production unit of the Alumunium "SP" factory. Data were analyzed by using univariate, bivariate, and multivariate analyses. Results: This study found age to increase risk factors for work fatigue $(O R=2.52)$. The period of work is another risk factor that affects work fatigue $(\mathrm{OR}=2.36)$. Work attitudes and workload are also risk factors for work fatigue $(O R=2.4$ and $O R=3.18)$. Meanwhile, nutritional status, sleep duration and smoking are not risk factors for work fatigue. Multivariate analysis showed that the most influencing variable of work fatigue was work attitude ( $p$-value $=0.022$ ) with risk level 3 times greater in work attitude of weight category and age $p$-value $=0.019$ with risk level 3 times greater in people aged $>35$ years. Conclusion: We found that work attitudes, workload, age, length of service, sleep duration can affect work fatigue while nutritional status and smoking habits had no effect on work fatigue.
\end{abstract}

Keywords: workload; individual factors; fatigue; work attitude

\footnotetext{
${ }^{1}$ Departemen Perilaku Kesehatan, Lingkungan dan Kedokteran Sosial, Fakultas Kedokteran, Universitas Gadjah Mada (Email: elinachrisniati@yahoo.com)

${ }^{2}$ Departemen Anatomi, Fakultas Kedokteran, Universitas Gadjah Mada
} 


\section{PENDAHULUAN}

Peran tenaga manusia sampai saat ini merupakan hal utama dalam proses produksi. Tidak sedikit proses produksi yang masih menggunakan peralatan manual dan melibatkan peran manusia atau dikenal dengan pekerjaan manual. Manusia memiliki keterbatasan khususnya segi fisik, sehingga dapat menimbulkan kelelahan (1). Kelelahan kerja merupakan salah satu dari gangguan kesehatan yang dialami oleh pekerja akibat dari pekerjaan yang dilakukan (2). Kelelahan karena aktivitas kerja berulang dapat memunculkan risiko cedera tubuh. Energi yang tidak sesuai dengan yang dilakukan akan mempercepat seseorang merasa lelah (3). Dampak yang ditimbulkan oleh kelelahan telah dikemukakan oleh International Labour Organization (ILO) yang menyebutkan bahwa setiap tahun 2 juta pekerja meninggal dunia karena kecelakaan kerja yang disebabkan faktor kelelahan. Tahun 2002-2004, dari 134 kecelakaan fatal 11\% disebabkan oleh faktor kelelahan di New Zealand, sedangkan, pada tahun 2004 tercatat 414 kecelakaan kerja di Indonesia, 27,8\% disebabkan oleh faktor kelelahan dan 9,5\% mengalami kecacatan. Penyebab kelelahan di industri sangat bervariasi. Beban kerja yang tinggi dan sikap kerja yang tidak ergonomis dapat mempercepat kelelahan pada pekerja (4). Kelelahan dapat terjadi karena interaksi antara pekerja dengan pekerjaan. Kelelahan kerja jika dihubungkan dengan prinsip ergonomi mencakup kesesuaian antara kondisi kerja dan kondisi pekerja itu sendiri (5). Apabila pekerjaan yang dilakukan melebihi batas kemampuan yang dimiliki, kecenderungan pekerja mengalami kelelahan kerja akan meningkat. Faktor-faktor pencetus kelelahan kerja berasal dari individu pekerja dan pekerjaan (6). Beberapa masalah yang ditemukan yaitu sebagian besar cara kerja tidak dilakukan dengan ergonomis seperti posisi kerja jongkok, teknik pengangkatan beban yang keliru dan sifat pekerjaan yang cepat karena pekerja dituntut untuk mengejar target sehingga pekerja berisiko mengalami kecelakaan kerja. Penelitian ini bertujuan untuk mengetahui apakah sikap kerja, beban kerja dan faktor individu berpengaruh terhadap kelelahan kerja pada pekerja pabrik unit produksi alumunium 'SP' Yogyakarta.

\section{METODE}

Penelitian cross-sectional dilakukan pada unit produksi alumunium 'SP' melibatkan total sampling berjumlah 100 orang. Instrumen penelitian menggunakan lembar isian untuk mengetahui faktor individu. Microtoise dan timbangan injak digunakan untuk mengetahui tinggi badan dan berat badan. Kamera digital, video camera recorder, stopwatch dan checklist digunakan untuk menilai sikap kerja. Reaction timer digunakan untuk mengukur kelelahan kerja. Kuat hubungan digambarkan dengan nilai Odds Ratio. Keseluruhan uji menggunakan Confidence Interval 95\% dan tingkat kemaknaan $p$ value 0,05.

\section{HASIL}

Tabel 1 menunjukkan hasil odd ratio untuk masing-masing variabel penelitian.

Tabel 1. Odd ratio untuk masing-masing variabel penelitian

\begin{tabular}{|c|c|c|c|}
\hline Variabel & $\begin{array}{c}\text { Belum lelah } \\
(n=32)\end{array}$ & $\begin{array}{l}\text { Lelah } \\
(\mathrm{n}=68)\end{array}$ & $\begin{array}{c}\text { OR } \\
\text { (CI 95\%) }\end{array}$ \\
\hline \multicolumn{4}{|l|}{ Sikap kerja } \\
\hline Sedang & 16 & 20 & $2.4^{*}$ \\
\hline Berat & 16 & 48 & $(0.92-6.24)$ \\
\hline \multicolumn{4}{|l|}{ Beban kerja } \\
\hline Sedang & 24 & 33 & $3.18^{*}$ \\
\hline Berat & 8 & 35 & $(1.16-9.29)$ \\
\hline \multicolumn{4}{|l|}{ Usia (tahun) } \\
\hline$\leq 35$ & 14 & 16 & $2.52 *$ \\
\hline$>35$ & 18 & 52 & $(0.93-6.77)$ \\
\hline \multicolumn{4}{|c|}{ Masa kerja (tahun) } \\
\hline$<10$ & 17 & 22 & $2.36^{*}$ \\
\hline$\geq 10$ & 15 & 46 & $(0.91-6.12)$ \\
\hline \multicolumn{4}{|l|}{ Status gizi } \\
\hline Normal & 22 & 43 & 1.27 \\
\hline Tidak normal & 10 & 25 & $(0.48-3.53)$ \\
\hline \multicolumn{4}{|c|}{ Kebiasaan merokok } \\
\hline Tidak merokok & 15 & 24 & 1.61 \\
\hline Merokok & 17 & 44 & $(0.62-4.13)$ \\
\hline \multicolumn{4}{|c|}{ Durasi tidur (jam) } \\
\hline$\leq 5$ & 16 & 48 & $0.41^{*}$ \\
\hline$>5$ & 16 & 20 & $(0.16-1.08)$ \\
\hline
\end{tabular}

Analisis multivariat dilakukan menggunakan 4 tahap. Tahap pertama diperoleh variabel sikap kerja, beban kerja, usia, masa kerja dan durasi tidur. Setelah melakukan uji pada beberapa tahap diperoleh model ke 4 dengan variabel sikap kerja dan usia. 
Tabel 2. Hasil analisis multivariat variabel usia, masa kerja, durasi tidur, dan beban kerja

\begin{tabular}{|c|c|c|c|c|c|c|}
\hline \multirow[b]{2}{*}{ Model } & \multirow[b]{2}{*}{ Variabel } & \multirow[b]{2}{*}{ OR } & \multicolumn{2}{|c|}{ CI 95\% } & \multirow[b]{2}{*}{$\begin{array}{l}\text { Nilai } \\
\text { ROC }\end{array}$} & \multirow[b]{2}{*}{$p$-value } \\
\hline & & & $\begin{array}{c}\text { Batas } \\
\text { Bawah }\end{array}$ & $\begin{array}{c}\text { Batas } \\
\text { Atas }\end{array}$ & & \\
\hline \multirow[t]{5}{*}{1} & Usia & 3,24 & 1,17 & 8,96 & \multirow{5}{*}{0,75} & 0,023 \\
\hline & $\begin{array}{l}\text { Masa } \\
\text { Kerja }\end{array}$ & 2,12 & 0,79 & 5,68 & & 0,131 \\
\hline & $\begin{array}{l}\text { Durasi } \\
\text { Tidur }\end{array}$ & 0,44 & 0,17 & 1,17 & & 0,120 \\
\hline & $\begin{array}{l}\text { Sikap } \\
\text { Kerja }\end{array}$ & 2,56 & 0,95 & 6,87 & & 0,061 \\
\hline & $\begin{array}{l}\text { Beban } \\
\text { Kerja }\end{array}$ & 2,20 & 0,77 & 6,23 & & 0,138 \\
\hline \multirow[t]{4}{*}{2} & Usia & 3,15 & 1,16 & 8,54 & \multirow{4}{*}{0,73} & 0,024 \\
\hline & $\begin{array}{l}\text { Masa } \\
\text { Kerja }\end{array}$ & 2,66 & 1,04 & 6,80 & & 0,040 \\
\hline & $\begin{array}{l}\text { Durasi } \\
\text { Tidur }\end{array}$ & 0,40 & 0,12 & 1,46 & & 0,059 \\
\hline & $\begin{array}{l}\text { Sikap } \\
\text { Kerja }\end{array}$ & 2,88 & 1,10 & 7,56 & & 0,031 \\
\hline \multirow[t]{3}{*}{3} & Usia & 3,10 & 1,17 & 8,21 & \multirow{3}{*}{0,70} & 0,022 \\
\hline & $\begin{array}{l}\text { Masa } \\
\text { Kerja }\end{array}$ & 2,45 & 0,98 & 6,08 & & 0,053 \\
\hline & $\begin{array}{l}\text { Sikap } \\
\text { Kerja }\end{array}$ & 3,08 & 1,19 & 7,96 & & 0,020 \\
\hline \multirow[t]{2}{*}{4} & Usia & 3,13 & 1,20 & 8,12 & \multirow[b]{2}{*}{0,67} & 0,019 \\
\hline & $\begin{array}{l}\text { Sikap } \\
\text { Kerja }\end{array}$ & 2,95 & 1,17 & 7,45 & & 0,022 \\
\hline
\end{tabular}

\section{BAHASAN}

\section{Sikap kerja dengan kelelahan kerja.}

Sikap tubuh dalam bekerja merupakan gambaran tentang kaitan posisi badan, kepala, dan anggota tubuh lainnya (21). Sikap kerja merupakan titik penentu untuk meng- analisis kefektifan dari suatu pekerjaan. Apabila sikap kerja yang dilakukan sudah baik dan ergonomis maka dapat dipastikan hasil yang diperoleh pekerja akan baik. Akan tetapi, bila sikap kerja pekerja tidak ergo- nomis maka pekerja akan mudah mengalami kele- lahan (7).

Terdapat pengaruh sikap kerja terhadap kelelahan kerja. Hal ini disebabkan karena di unit produksi SP Alumunium sebagian besar sikap kerja pekerja tidak ergonomis. Hal ini membuat pekerja mengalami kelelahan. Hasil penelitian ini sejalan dengan penelitian yang menjelaskan bahwa bekerja secara tidak ergonomis berpengaruh terhadap kelelahan (8). Hasil penelitian ini diperkuat dengan penelitian yang menyatakan, sikap kerja dengan sistem kerja yang tidak sehat akan menyebabkan kelelahan (9). Hal ini sejalan dengan penelitian yang menjelaskan bahwa sikap kerja tidak ergonomis berpengaruh terhadap kelelahan (10). Pematung yang melakukan sikap kerja tidak ergonomis akan memengaruhi kelelahan (4). Sikap kerja yang tidak ergonomis dapat memengaruhi kelelahan para pekerja (1).

\section{Beban kerja dengan kelelahan kerja.}

Beban kerja adalah kemampuan tubuh pekerja dalam menerima pekerjaan. Dari sudut pandang ergonomi, setiap beban kerja yang diterima seseorang harus sesuai dan seimbang terhadap kemampuan fisik maupun psikologis pekerja yang menerima beban kerja tersebut (11). Ukuran beban kerja yang diterima oleh seorang pekerja dapat digunakan untuk menentukan berapa lama seorang pekerja dapat melakukan aktivitas pekerjaan sesuai dengan kemam-puan atau kapasitas kerja yang dimiliki. Semakin berat beban kerja, akan semakin pendek waktu kerja seseorang untuk bekerja tanpa kelelahan (12).

Penelitian ini menemukan beban kerja adalah faktor risiko kelelahan kerja. Semakin besar tingkat beban kerja maka semakin besar risiko kelelahan kerja. Hasil penelitian ini sejalan dengan penelitian yang menyatakan bahwa pengaruh yang paling dominan terhadap kelelahan adalah beban kerja (13). Beban kerja berat akan berpengaruh terhadap kelelahan kerja (14). Penelitian lain menemukan terdapat pengaruh antara beban kerja terhadap kelelahan pekerja industri kereta api (15). Beban kerja menjadi faktor utama kelelahan pada Pegawai Badan Pertanahan Nasional Samarinda (16).

\section{Usia dengan kelelahan kerja.}

Usia dapat memengaruhi kondisi fisik seseorang. Seseorang yang berumur lebih muda sanggup melakukan pekerjaan berat, sebaliknya seseorang berusia lanjut, kemam- puan dalam melakukan pekerjaan berat akan menga- lami penurunan (17). Usia juga berpengaruh terhadap kelelahan kerja. Pekerja dengan usia lebih tua rentan mengalami penurunan kekuatan otot (18).

Terdapat pengaruh antara usia dengan kelelahan kerja. Hal ini dapat disebabkan karena tidak ada pembagian jenis kerja berdasarkan usia. Sebagian pekerja usia tua malah ditempatkan di unit yang membutuhkan kekuatan fisik cukup tinggi. Hasil penelitian ini menyatakan bahwa perawat yang lebih tua berkon- tribusi besar terhadap kelelahan (19). Usia tua meru- pakan salah satu faktor yang berpengaruh terhadap kelelahan (20, 21). Sebagian besar sistem fisiologis berkurang dan kerentanan terhadap berbagai penya- kit meningkat seiring dengan pertambahan usia (22).

\section{Masa kerja dengan kelelahan kerja.}

Semakin lama seseorang bekerja, akan timbul perasaan jenuh akibat kerja monoton dan 
berpengaruh terhadap ting- kat kelelahan yang dialami (18). Hasil analisis bivariat antara masa kerja dengan kelelahan kerja menun- jukkan terdapat pengaruh yang signifikan. Lama masa kerja berkaitan dengan pengalaman yang dimiliki, tetapi semakin lama masa kerja semakin besar pula tingkat risiko terpapar bahaya dalam lingkungan kerja.

Hasil penelitian ini sejalan dengan penelitian yang menyatakan bahwa kelelahan pekerja pada bagian tenaga bongkar muat dipengaruhi oleh masa kerja (23). Hasil ini diperkuat dengan penelitian yang menyatakan bekerja $>5$ tahun akan mempercepat kontraksi otot, dengan kata lain pengaruh masa kerja signfikan terhadap kelelahan kerja (24). Hasil penelitian ini sesuai dengan penjelasan bahwa masa kerja yang lama berpengaruh terhadap kelelahan (25). Hasil ini ditunjang dengan pembuktian bahwa masa kerja yang lama memiliki hubungan terhadap kelelahan walau aspek pengalaman, kematangan dan mental tinggi (26).

\section{Status gizi dengan kelelahan kerja.}

Penelitian ini menemukan tidak ada pengaruh status gizi terhadap kelelahan kerja. Hal ini disebabkan oleh masa kerja responden yang tergolong sudah lama. Masa kerja yang lama berkaitan dengan banyak pengalaman yang dimiliki oleh pekerja dan pengalaman tersebut akan membuat kemampuan dalam bekerja dan bertindak semakin matang. Hasil penelitian ini sejalan dengan penelitian yang dilakukan oleh Setyowati yang menya- takan bahwa status gizi tidak berpengaruh terhadap kelelahan kerja (27). Hasil penelitian lain menemukan bahwa status gizi pada pekerja weaving tidak berpengaruh signifikan dengan kelelahan kerja (28). Sesuai dengan penelitian pada pekerja catering menjelaskan bahwa status gizi pekerja tidak berpe- ngaruh terhadap kelelahan kerja (29). Penelitian tersebut sesuai dengan penelitian yang menyatakan bahwa status gizi tidak berpengaruh terhadap kele- lahan kerja (30). Pada penelitian di industri roti, sebanyak 26 orang menyebutkan bahwa status gizi tidak berpengaruh terhadap kelelahan (31).

\section{Kebiasaan merokok dengan kelelahan kerja.}

Kebiasaan merokok tidak berpengaruh terhadap kelelahan kerja. Bagi pekerja, merokok dapat memberikan sugesti positif. Hasil penelitian ini sejalan dengan penelitian yang menyatakan saat tidak merokok, pekerja akan merasa kondisi badan tidak enak dan tidak bisa berkonsentrasi (32). Sejalan dengan penelitian lain yang menyebutkan bahwa mayoritas perokok pada pekerja perempuan tidak memengaruhi kelelahan kerja (33). Kebiasaan merokok tidak berpengaruh terhadap kelelahan (34). Perokok merasa mendapatkan stimulasi jika merokok. Hal ini menjelaskan bahwa tidak ada pengaruh merokok dengan kelelahan (35).

\section{Durasi tidur dengan kelelahan kerja.}

Circardian rhythms merupakan proses yang dialami tubuh untuk menyesuaikan dengan perubahan waktu selama 24 jam (36). Proses pemulihan yang terhambat menye- babkan organ tubuh tidak bekerja maksimal, sehingga orang yang kurang tidur akan cepat lelah (37).

Terdapat pengaruh antara durasi tidur dengan kelelahan kerja. Lama intensitas bekerja juga berpengaruh terhadap jumlah jam tidur setiap hari. Tidur berpengaruh pada daya tahan tubuh dalam melakukan pekerjaan. Jam tidur yang kurang setiap hari akan berpengaruh terhadap kelelahan kerja. Hasil ini sejalan dengan penelitian yang menyatakan bahwa pekerja minimarket yang mengalami tidur yang kurang akan mengalami kelelahan (38). Penyebab utama kelelahan kerja di Jepang yaitu faktor tidur pekerja yang kurang (39). Dalam penelitian tersebut, kekurangan tidur akan mengakibatkan tingkat kewaspadaan pekerja menurun (40). Hal ini sesuai dengan penjelasan bahwa durasi tidur pada dosen berpengaruh pula dengan tingkat kelelahan (41). Pekerja yang mengalami insomnia memiliki durasi tidur yang kurang, sehingga menyebabkan kelelahan (42).

\section{SIMPULAN}

Sikap kerja, beban kerja, usia, masa kerja dan durasi tidur memengaruhi kelelahan kerja. Sementara, status gizi dan kebiasaan merokok tidak berpengaruh terhadap kelelahan kerja.

Perlu ada pengaturan beban kerja pada setiap unit produksi dan memberikan waktu istirahat yang lebih khususnya pada unit peleburan, cetak kering dan cetak basah.
Abstrak
Tujuan: Penelitian ini bertujuan untuk mengetahui
pengaruh usia, masa kerja, status gizi, durasi tidur,
kebiasaan merokok sikap kerja dan beban kerja
terhadap kelelahan kerja pada pekerja pabrik unit
produksi "SP" alumunium Kota Yogyakarta.
Metode: Penelitian ini merupakan penelitian 
observasional analitik dengan menggunakan studi cross sectional. Populasi berjumlah 153 orang dan sampel diambil berdasarkan total sampling pada unit produksi pabrik "SP" Alumunium. Data dianalisis dengan menggunakan analisis univariat, bivariat dan multivariat. Hasil: Penelitian ini menemukan usia merupakan faktor risiko kelelahan kerja $(\mathrm{OR}=2,52)$. Masa kerja adalah faktor risiko lain yang memengaruhi kelelahan kerja $(\mathrm{OR}=2,36)$. Sikap kerja dan beban kerja juga merupakan faktor risiko kelelahan kerja $(\mathrm{OR}=2,4$ dan $\mathrm{OR}=3,18$ ). Status gizi, durasi tidur dan kebiasaan merokok bukan faktor risiko kelelahan kerja. Analisis multivariat menunjukkan variabel yang paling memengaruhi kelelahan kerja adalah sikap kerja ( $p$-value $=0,022$ ) dengan tingkat risiko 3 kali lebih besar pada sikap kerja kategori berat dan usia $p$-value $=0,019$ dengan tingkat risiko 3 kali lebih besar pada orang usia >35 tahun. Simpulan: Sikap kerja, beban kerja, usia, masa kerja dan durasi tidur memengaruhi kelelahan kerja sedangkan variabel status gizi dan kebiasaan merokok tidak mempunyai pengaruh terhadap kelelahan kerja.

Kata Kunci: beban kerja; faktor individu; kelelahan; sikap kerja

\section{PUSTAKA}

1. Bukhori E. Hubungan faktor risiko pekerjaan dengan terjadinya keluhan musculokeletal disorders (MSDs) pada tukang angkut beban penambang emsa di kecematan cilograng kabupaten lebak Banten tahun 2010.

2. Tarwaka SH, Sudiajeng L. Ergonomi untuk keselamatan, kesehatan kerja dan produktivitas. UNIBA, Surakarta. 2004.

3. Silastuti, A. Hubungan antara Kelelahan dengan Produktivitas Tenaga Kerja di Bagian Penjahitan PT Bengawan Solo Garment Indonesia. Skripsi. Semarang: Universitas Negeri Semarang; 2006.

4. Sutajaya, I.M., Ristiati, N.P. Perbaikan Kondisi Kerja Berbasis Kearifan Lokal Yang Relevan Dengan Konsep Ergonomi Untuk Meningkatkan Kualitas Kesehatan Dan Produktivitas Pematung di Desa Peliatan Ubud Gianyar. Jurnal Penelitian Dan Pengembangan Sains Dan Humaniora; 2011 Vol. 5 (3), hal. 259-270.

5. Nurmianto, E. Ergonomi Konsep Dasar dan Aplikasinya Edisi Kedua. Surabaya: Guna Widya. 2004.

6. Setyawati. Handout, PAK Hiperkes. Yogyakarta: Universitas Gadjah Mada. 2002.

7. Susihono W, Prasetyo W. Perbaikan postur kerja untuk mengurangi keluhan muskuloskeletal dengan pendekatan metode owas (Studi Kasus Di
UD. Rizki Ragil Jaya-Kota Cilegon). Spektrum Industri. 2012 Apr 1;10(1).

8. Arief, A., Erzeddin, A., Zikra. Pengaruh Stasiun Kerja Terhadap Kelelahan dan Waktu Kerja Mekanik Sepeda Motor di Kotamadya Padang. Prosiding Seminar Nasional "Keselamatan Dan Kesehatan Kerja”. Univeristas Gadjah Mada, hal.173-179. 2013.

9. Sari WN. Hubungan antara Sikap Kerja Duduk dengan Keluhan Subyektif Nyeri Punggung Bawah pada Pekerja Pembuat Terasi di Tambak Rejo Tanjung Mas Semarang. Unnes Journal of Public Health. 2013;2(2).

10. Mariyam S, Pertiwi KR. Faktor Determinan Tingkat Stres Dan Kelelahan Kerja Karyawan Universitas Negeri Yogyakarta. Jurnal Sains Dasar. 2015;4(2):114-21.

11. Manuaba, A. Penerapan Ergonomi Meningkatkan Produktivitas. Makalah Denpasar: Universitas Udayana. 2000.

12. Tarwaka SH, Sudiajeng L. Ergonomi untuk keselamatan, kesehatan kerja dan produktivitas. UNIBA, Surakarta. 2004.

13. Ihsan T, Salami IR. Hubungan Antara Bahaya Fisik Lingkungan Kerja dan Beban Kerja Dengan Tingkat Kelelahan Pada Pekerja Di Divisi Stamping PT. X Indonesia. Jurnal Dampak. 2015 Jan 1;12(1):10-6.

14. Wati, M.M., Hariyono, W. Hubungan Antara Beban Kerja Dengan Kelelahan Kerja Karyawan Laundry Di Kelurahan Warungboto Kecamatan Umbulharjo Kota Yogyakarta. Jurnal Kesmas UAD; 2011 Vol. 5 (3), 162-232.

15. Dorrian J, Baulk SD, Dawson D. Work hours, workload, sleep and fatigue in Australian Rail Industry employees. Applied ergonomics. 2011 Jan 1;42(2):202-9.

16. Rambulangi, C.J. Hubungan Antara Beban Kerja dengan Kelelahan Kerja Pegawai Badan Pertanahan Nasional Tingkat II Samarinda. Psikoborneo; 2016 Vol. 4 (2), hal. 292-300.

17. Suma'mur, P.K. Ergonomi Untuk Meningkatkan Produktivitas Kerja. Jakarta: CV. Haji Masagung; 1989.

18. Setyawati L. Selintas tentang kelelahan kerja. Yogyakarta: Amara Books. 2010.

19. Winwood PC, Lushington K, Winefield AH. The contribution of age, domestic responsibilities and shiftwork to work-related fatigue and recovery within a sample of full-time Australian nurses. Journal of Advanced Nursing. 2006;56(4):438-49.

20. Hallowell, M.R. Worker Safety. Worker Fatigue. Managing Concerns In Rapid Renewal Highway Construction Project. The American Society of Safety Engineers. 2010. Diakses Melalui Www.Assse.Org/Professionalsafety Pada Tanggal 15 September 2016.

21. Kocalevent RD, Hinz A, Brähler E, Klapp BF. Determinants of fatigue and stress. BMC research notes. 2011 Dec;4(1):238.

22. Bonder, B.R., Haas. V.D.B. Functional Performance in Older Adults. David Company. Philadelphia; 2009.

23. Elia, K. P., Josephus, J., Tucunan, A. T. Hubungan Antara Kelelahan Kerja Dan Masa Kerja Dengan Produktivitas Kerja Pada Tenaga Kerja Bongkar Muat Di Pelabuhan Bitung. Jurnal Ilmiah Farmasi; 2009 Vol. 5 (2), hal. 107-113.

24. Langgar DP, Setyawati VA. Hubungan antara asupan gizi dan status gizi dengan kelelahan 
kerja pada karyawan perusahaan Tahu Baxo Bu Pudji Di Unggaran Tahun 2014. Jurnal FKM Dian Nuswantoro Semarang. Diakses. 2014;16:03-15.

25. Mentari A, Kalsum SA. Hubungan Karakteristik Pekerja dan Cara Kerja dengan Kelelahan Kerja pada Pemanen Kelapa Sawit di PT. Perkebunan Nusantara IV (PERSERO) Unit Usaha Adolina: Fakultas Kesehatan Masyarakat Universitas Sumatera Utara. Medan. 2012.

26. Robbins, S.P. Organizational Behavior: Concepts, Controversies, Applications. New Jersey: Prentice-Hall, Inc;

27. Setyowati DL, Shaluhiyah Z, Widjasena B. Penyebab Kelelahan Kerja pada Pekerja Mebel. Kesmas: National Public Health Journal. 2014 May 1;8(8):386-92.

28. Triyunita, N., Ekawati., Daru, L. Hubungan Beban Kerja Fisik, Kebisingan Dan Faktor Individu dengan Kelelahan Pekerja Bagian Weaving Pt.X Batang. Jurnal Kesehatan Masyarakat; 2013 Vol. 2 (2).

29. Ramayanti R. Analisis Hubungan Status Gizi Dan Iklim Kerja Dengan Kelelahan Kerja Di Catering Hikmah Food Surabaya. The Indonesian Journal of Occupational Safety and Health. 2017 Mar 16;4(2):177-86.

30. Chesnal H, Raitu AJ, Lampus BS. Hubungan antara Umur, Jenis Kelamin, dan Status Gizi dengan Kelelahan Kerja pada Tenaga Kerja di Bagian Produksi PT. Putra Karangetang Popontelen Minahasa Selatan. Jurnal Kesehatan Masyarakat. 2012:12-5.

31. Nainggolan, R.S.D. Hubungan Beban Kerja Dan Karakteristik Tenaga Kerja Dengan Kelelahan Pada Tempat Kerja Yang Bertekanan Panas (Studi Di Industri Roti Di Kabupaten Jepara). Tesis. Univeritas Diponegoro. Semarang; 2010.

32. Rahayu, R.N.B. Pengaruh Metode 5As Terhadap Sikap Rokok. Tesis. Universitas Sebelas Maret; 2010.

33. Weingarten TN, Vincent A, Luedtke CA, Beebe TJ, Welch TL, Chong EY, Schroeder DR, Warner DO.
The perception of female smokers with fibromyalgia on the effects of smoking on fibromyalgia symptoms. Pain Practice. 2016 Nov 1;16(8):1054-63.

34. Ridwansyah., Nurbeti, M., Sunarto. Faktor-Faktor yang Berhubungan dengan Kelelahan pada Lanjut Usia di Desa Umbulmartani, Sleman Tahun 2015. JKKI; 2015 Vol. 6 (4), hal. 188-197.

35. Gaghiwu, L., Josephus, J., Rompas, R.M. Analisis Beberapa Faktor Penyebab Kelelahan Kerja Pada Tenaga Bongkar Buat Di Pelabuhan Samudera Bitung. Paradigma, Vol. 4 (1); 2016, hal. 59-70.

36. Tayyari. F., Smith. J.L. Occupational Ergonomics: Principles and Applications. Chaman \& Hall. London; 1997.

37. Diani, A.W. Faktor-Faktor yang Mempengaruhi Kecenderungan Kesulitan Tidur Pada Mahasiswa yang Menyusun Skripsi. Tesis. Surabaya: UIN Sunan Ampel; 2014.

38. Wulandari. I. N.,Adiputra. L.M.I.S.H., Hubungan Gangguan Tidur Dengan Kelelahan Pada Sistem Kerja Bergilir (Shift) Malam Terhadap Karyawan Minimarket 24 Jam Di Kota Denpasar. The Indonesian Journal Of Ergonomic; 2015 Volume 1, No 1, 2015 Hal 51-60.

39. Hamaguchi, M., Kawahito, Y., Takeda, N., Kato, T., Kojima, T. Characteristics of Chronic Fatigue Syndrom In Japanese Community Population; Chronic Fatigue Syndrome In Japan. Clin Rheumatol; 2011 Vol. 30 (7), pp. 895- 906.

40. Rose M, Giray N. Universal fatigue management strategies. Sleep Medicine Clinics. 2013 Jun 1;8(2):255-63.

41. Yogisutanti G, Kusnanto H, Setyawati L, Otsuka Y. Kebiasaan Makan Pagi, Lama Tidur dan Kelelahan Kerja (Fatigue) Pada Dosen. Jurnal Kesehatan Masyarakat. 2013;9(1):53-7.

42. Richter K, Acker J, Adam S, Niklewski G. Prevention of fatigue and insomnia in shift workers-a review of non-pharmacological measures. EPMA journal. 2016 Dec 1;7(1):16. 